\title{
Histamine Toxicity Resembles an Allergic Reaction: A Case Report
}

\author{
Noviana Joenputri ${ }^{1}$, Ketut Suryana ${ }^{2}$ \\ ${ }^{1}$ General Practitioner, Department of Internal Medicine, Wangaya General Hospital, Denpasar, Bali, Indonesia \\ ${ }^{2}$ Immunologist, Department of Internal Medicine, Wangaya General Hospital, Denpasar, Bali, Indonesia
}

\begin{abstract}
Food poisoning which is caused by fish is frequently diagnosed as allergic to fish because the symptoms caused by both conditions are very similar. To diagnose food poisoning which is caused by fish, it should be based on the history of the complaints and the history of the fish which has just been consumed. There is no specific supporting tests to diagnose this condition. We are reporting a case of a 30-year old male who showed symptoms similar to allergic reaction, which turned out to be caused by poisoning, 30 minutes after consuming mackarel fish. This food poisoning is a self-limiting disease. Prevention is very important in the management of food poisoning in order to prevent an outbreak.
\end{abstract}

Keywords: histamine toxicity, fish poisoning, food allergy, food intoxication

\section{Introduction}

Histamine toxicity is one of the forms of food poisoning which frequently goes undiagnosed because the symptoms are similar to food allergy. But actually, the underlying pathogenesis of these two reactions are different. Some food poisoning outbreaks occurred in America.[1] In Indonesia, several outbreaks were reported due to food poisoning which is caused by consumption of fish. Some types of fish can cause histamine toxicity reaction, mostly are from the Scombridae family, for example is tuna and mackarel. Both fishes are consumed daily by Indonesian people.

\section{Case Illustration}

A 30-year old male came to the Emergency Department and with complaints of swelling and redness on the face, as well as bumps and itchy all over the body. The patient indicated that the complaints occurred approximately 30 minutes after he ate mackarel fish in a food stall. The patient also complained about feeling weak, nauseous, vomiting, heavy breathing, and dizzy. The patient passed liquid stool two times without any residue, blood, and mucus. The patient was frequently consuming the same type of fish in different places, but never experience this before. The patient denied having any history of atopy or previous medical history. The patient was not on any routine medication.

From physical examination, it was found out that the blood pressure was $130 / 80 \mathrm{mmHg}$, tachycardia (the heart rate was 100 beats/minute), respiratory rate was 26 times/minute, $\mathrm{SpO} 2$ was $96 \%$, afebrile. There were flushing on the face and generalized urticaria. Examination on heart and lungs shows them to be within normal range. There was epigastric tenderness and increased bowel sounds. The white blood cells count was $15,500 / \mathrm{uL}$; hemoglobin count was $16.1 \mathrm{~g} / \mathrm{dl}$; hematocrit was $45.2 \%$; platelet count was $182,000 / \mathrm{uL}$; neutrophil count was $85.7 \%$; eosinophil count was $0.5 \%$.

In the Emergency Department, the patient was given oxygen with flow rate of $2 \mathrm{lpm}$, and then observed in the inpatient ward. Patient received intravenous liquid therapy, oral loratadine $10 \mathrm{mg}$ twice daily, and methylprednisolone injection $62.5 \mathrm{mg}$ twice daily. Patient was hospitalized for five days. On the first day of hospitalization, flushing, bumps, and itchiness on the skin were resolved. During hospitalization, the patient still frequently felt nauseous and experienced diarrhea. On the fourth day, complaints such as nausea, vomiting, diarrhea, and heavy breathing had been resolved.

\section{Discussion}

Histamine toxicity, which is also known as scromboid poisoning, is one of the forms of food poisoning. According to the Food and Drug Administration (FDA) in the United States of America, the type of fish which most frequently cause histamine toxicity is the member of Scombridae family (tuna and mackarel). Some non-scromboid fishes, such as bluefish, dolphin or mahi mahi, and amberjack can also cause histamine toxicity.[2]

Diagnosis of scromboid poisoning is frequently underdiagnosed. This is because the symptoms of scromboid poisoning is similar to te acute allergic reaction. Scromboid poisoning occurred on fish due to inadequate processing and storage. The best storage for fish is at below or equal to $0^{0} \mathrm{C}$. If fish is stored in a temperature above $4^{0} \mathrm{C}$, this condition will be beneficial for bacterial growth, which will trigger the conversion of histidine in the fish meat to histamine through enzyme activity in the bacteria, i.e. histidine decarboxylase. $[3,4]$. Histidine decarboxylase is found in the bacteria which presents in the gills and digestive tract of fish. The species of bacteria which have histidine decarboxylase activity includes Proteus, Enterobacter, Serratia, Citrobacter, Escherichia coli, Clostridium, Vibrio, Acinetobacter, Pseudomonas, and Photobacterium.[5,6] Another thing which caused this diagnosis of scromboid poisoning is that the histamine presents in the fish does not

change the organoleptic quality, and hence the fish looks normal.[7] Therefore, the appearance, taste, and smell of the

Volume 9 Issue 1, January 2020 www.ijsr.net 


\section{International Journal of Science and Research (IJSR) \\ ISSN: 2319-7064}

ResearchGate Impact Factor (2018): 0.28 | SJIF (2018): 7.426

fish cannot be used as parameters for the presence of histamine. Histamine is also stable in heat and will still be there even after being cooked, frozen, smoked, or canned.[3,7]

Conversion of histamine requires several hours, but if the fish is stored in $20^{\circ} \mathrm{C}$, the level of toxic histamine can be accummulated only within two hours. The level of histamine of more than $50 \mathrm{mg} / 100$ grams of fish, can trigger clinical manifestation in scromboid poisoning (the level of histamine of fresh fish is less than $0.01 \mathrm{mg} / 100 \mathrm{~g}$ ).[3]

Clinical symptoms of scromboid poisoning is caused by the causative agent, i.e. histamine. Histamine is an endogenous amine compound which has several biological effects, such as vasodilation, activation of $\mathrm{H} 1$ receptor which causes rapid allergic response, and activation of $\mathrm{H} 3$ receptor which modulates the release of neurotransmitters in the central nervous system, which can cause nausea, vomiting, and headache. $[8,9]$

The most frequent symptom is flushing on the face, abdominal pain, diarrhea, headache, and palpitation, which occurs 20-30 minutes after consuming fish. Other symptoms include redness on the neck and waist or generalized flushing, nausea, vomiting, urticaria, dry mouth, feeling of floating, and rarely occur is wheezing or loss of consciousness due to hypotension.[4] On this patient, the symptoms occurred 30 minutes after consuming mackarel fish. The complaints of the patient were feeling weak, nauseous, vomiting, heavy breathing, dizzy, and diarrhea. These symptoms are due to the high level of histamine in the mackarel fish, which caused biological effects on the patient, such as vasodilation which caused redness on the face of the patient, activation of $\mathrm{H} 1$ receptor which caused rapid allergic response, such as generalized urticaria, itchiness, and heavy breathing, as well as activation of $\mathrm{H} 3$ receptor which caused nausea, vomiting, and dizziness.

However, most of the symptoms are mild and can be healed by itself within 12-28 hours.[4] Symptoms due to severe reaction, such as hypotension, bronchospasm, respiratory distress, and myocardial infarction, are rarely occurred.[10] These symptoms are similar to allergic reaction, hence in the reality, this histamine toxicity reaction is frequently misdiagnosed as IgE-mediated fish allergic reaction.[3]

There is no specific diagnostic test for scromboid poisoning in human. Diagnosis is confirmed based on the history of complaints and history of the fish which has just been consumed.[11] On scromboid poisoning, the patient in this case did not have any history of similar complaints when he previously consumed the same type of fish. If the patient has a similar history of complaints when he consumed the same type of fish, then it would lead to food allergic reaction.[3,12]

Some laboratory tests can support the diagnosis of scromboid poisoning, such as the level of histamine of the fish is $>50$ $\mathrm{mg} / 100 \mathrm{~g}$, and the plasma level of histamines and the level of histamine metabolites, such as (N-methylhistamine), in the urine are increased.[3,13] However, due to the limitation of supporting facilities in our place, the supporting tests were not performed.

Scromboid poisoning can be treated by giving antihistamine. For mild and moderate symptoms, oral $\mathrm{H} 1$ receptor antagonist. However, cetirizine is more preferable because of its milder sedative effect. $\mathrm{H} 2$ blocker, such as cimetidine, famotidine, or ranitidine can also be added. Normally the symptoms will be totally resolved within 6-8 hours. If the symptoms are severe, the administration of intramuscular epinephrine or dopamine titration and intravenous methylprednisolone can be considered.[3] This patient was treated with oral $\mathrm{H} 1$ antagonist, i.e. loratadine $10 \mathrm{mg}$ twice daily. In addition, the patient was also given oxygen and methyprednisolon injection because he showed quite severe symptom, i.e. heavy breathing. Complaints such as itchiness, redness, and bumps on the patient were resolved witin 24 hours after the onset. While nausea, vomiting, diarrhea, and heavy breathing were just resolved after being hospitalized for four days.

\section{Conclusion}

Scromboid poisoning is a disease which frequently goes undiagnosed. Therefore, it is recommended for clinicians to recognize this disease and differentiate it from allergic reaction. This disease is generally mild and self-limiting. Treatment is usually by using oral antihistamine for one to two days. This disease can be prevented by proper processing and storage of fish. Fish should be stored in a temperature below or equal to $0^{0} \mathrm{C}$ to prevent the bacterial growth on fish and to prevent activation of histidine decarboxylase. Each outbreak of scromboid poisoning should be reported to the Ministry of Health to prevent the increasing number of cases. Prevention is the key in managing this disease.

\section{References}

[1] National Marine Fisheries Service, F. S. D (2012) Fisheries of the United States, 2011. National Oceanic and Atmospheric Administration, Silver Spring.

[2] Scrombotoxin Poisoning and Decomposition. [Online]. Available: https://www.fda.gov/food/seafood-guidancedocuments-regulatory-information/scombrotoxinpoisoning-and-decomposition, [Accessed: Jan. 4, 2020].

[3] Feng C, Teuber S, Gershwin ME. Histamine (scombroid) fish poisoning: a comprehensive review. Clinical reviews in allergy \& immunology. $2016 \mathrm{Feb}$ 1;50(1):64-9.

[4] de Cerio OG, Barrutia-Borque A, Gardeazabal-García J. Scombroid poisoning: a practical approach. Actas Dermo-Sifiliográficas (English Edition). 2016 Sep 1;107(7):567-71.

[5] Lopez-Sabater EI, Rodriguez-Jerez JJ, HernandezHerrero M, Mora- Ventura MT (1996) Incidence of histamine-forming bacteria and his- tamine content in scombroid fish species from retail markets in the Barcelona area. Int J Food Microbiol 28:411-18.

[6] Tsai YH, Kung HF, Lee TM, Lin GT, Hwang DF. Histamine-related hygienic qualities and bacteria found 


\section{International Journal of Science and Research (IJSR) \\ ISSN: 2319-7064}

ResearchGate Impact Factor (2018): 0.28 | SJIF (2018): 7.426

in popular commercial scombroid fish fillets in Taiwan. Journal of Food Protection. 2004 Feb;67(2):407-12.

[7] Stratta P, Badino G. Scombroid poisoning. CMAJ. 2012;184(6):674.

[8] Smolinska S, Jutel M, Crameri R, O’Mahony L (2014) Histamine and gut mucosal immune regulation. Allergy 69:273-81.

[9] Hungerford JM (2010) Scombroid poisoning: a review. Toxicon 56: 231-43.

[10] Ascione A, Barresi LS, Sarullo FM, De Silvestre G (1997) Two cases of Bscombroid syndrome with severe cardiovascular compromise. Cardiologia 42:1285-8.

[11] Ferran M, Yébenes M. Flushing associated with scombroid fish poisoning. Dermatology online journal. 2006;12(6).

[12] O'Connor MM, Forbes GM. Scombroid poisoning: not fish allergy. Aust N Z J Med 2000;30:520.

[13] Morrow JD, Margolies GR, Rowland J, et al. Evidence that histamine is the causative toxin of scombroid-fish poisoning. N Engl J Med 1991;324:716-2.

Volume 9 Issue 1, January 2020

www.ijsr.net 